\title{
Race and Ethnicity in the Lives of LGBTQ Parents and Their Children: Perspectives from and Beyond North America
}

\author{
Amy Brainer, Mignon R. Moore, \\ and Pallavi Banerjee
}

In 2016, Black Lives Matter Toronto (BLM-TO) immobilized the Toronto Pride Parade to protest anti-Black racism in pride organizing and other LGBTQ spaces. Protestors presented pride organizers with a list of demands that centered queer and trans communities of color, including specific needs of Black, indigenous, and South Asian queer groups. ${ }^{1}$ The BLM-TO action and similar actions at pride parades in other Canadian and US cities are part of a legacy of protest and dialogue around issues of racial exclusion within LGBTQ communities. From the inception of LGBTQ movements in North America as well as in many European nations, activists of color have critiqued, disrupted, and at times successfully dismantled unjust structures and practices in

${ }^{1}$ For a complete list of demands and record of achievements, see: https://blacklivesmatter.ca/demands/ (retrieved September 5, 2018).

\author{
A. Brainer $(\bowtie)$ \\ Womens and Gender Studies and Sociology, \\ University of Michigan Dearborn, \\ Dearborn, MI, USA \\ e-mail: brainer@umich.edu \\ M. R. Moore \\ Sociology, Barnard College, Columbia University, \\ New York, NY, USA \\ e-mail: mmoore@barnard.edu \\ P. Banerjee \\ Sociology, University of Calgary, \\ Calgary, AB, Canada \\ e-mail: pallavi.banerjee@ucalgary.ca
}

society and within the movements themselves (see, for example, Alimahomed, 2010; Boston \& Duyvendak, 2015; Chambers-Letson, 2018; Stormhøj, 2018). The BLM-TO protest was responsive as well to a contemporary climate in which White supremacy, nationalism, homonationalism, and a variety of anti-Black and antiimmigrant measures structure people's daily lives. It is in this climate that queer and trans people form and sustain their families. Thus, as the BLM-TO protestors stressed, in order to adequately understand, represent, and support LGBTQ communities, it is necessary to see race and address racial oppression.

In the USA today, Black, indigenous, and Latinx $^{2}$ LGBTQ people are the most likely among all LGBTQ people to be raising children (Kastanis \& Wilson, 2014). Johnson (2018) writes that when he began conducting interviews with Black queer southern women, he had no idea how powerful a role motherhood would play in their lives or how deeply the desire to have children would run for many of his interviewees. A growing number of scholars focus on LGBTQ parents of color and push queer theories and methodologies to be more responsive to issues of race, class, citizenship, and colonialism (e.g., Acosta, 2013, 2018; Battle, Pastrana, \&

\footnotetext{
${ }^{2}$ See Salvador Vidal Ortiz and Juliana Martínez, "Latinx Thoughts: Latinidad with an X" (2018) for a discussion of contestations around Latinx and its connections to other forms of linguistic resistance.
} 
Harris, 2017a, 2017b; Glass, 2014; Karpman, Ruppel, \& Torres, 2018; Leibetseder, 2018; Moore, 2011a, 2011b; Pastrana, Battle, \& Harris, 2017; Rodriguez, 2014). At the same time, White lesbian and gay parents remain overrepresented in the literature on LGBTQ-parent families as well as in popular culture (see Bible, Bermea, van Eeden-Moorefield, Benson, \& Few-Demo, 2018; Huang et al., 2010; Singh \& Shelton, 2011; van Eeden-Moorefield, Few-Demo, Benson, Bible, \& Lummer, 2018). As one Black gay father put it,

\footnotetext{
We're in the gay community, and the gay community itself is segregated. So we're the Black guys, you know, the Black section of the gay community. And then we're in a smaller-we're in the Black section with children in the gay community. We don't see our image around anywhere. (Carroll, 2018a, p. 111)
}

The invisibility articulated by this father goes beyond a politics of representation to reveal the interlocking systems of power that shape the lives of LGBTQ parents and their children. In this chapter, we highlight work by scholars who make the intersections of race, ethnicity, gender, and sexuality more central to the production of knowledge about LGBTQ-parent families.

\section{Theoretical Frameworks}

In the second edition of Black Feminist Thought: Knowledge, Consciousness and the Politics of Empowerment, Collins (2000) conceptualizes sexuality in three ways: as a freestanding system of oppression similar to oppressions of race, class, nation, and gender, as an entity that is manipulated within each of these distinctive systems of oppression, and as a social location or conceptual glue that binds intersecting oppressions together and shows how oppressions converge. In her later work, Collins (2004) theorizes sexuality through the lens of heterosexism, which she identifies as a system of power similar to racism, sexism, and class oppression that suppresses heterosexual and homosexual African Americans in ways that foster Black subordination. As we demonstrate in this chapter, Collins' (2004) application of the intersectionality paradigm to the study of Black women's sexuality is also a useful way to conceptualize sexuality as one of several social locations that LGBTQ parents inhabit.

LGBTQ group interests are often analyzed and advocated for in ways that privilege the interests of higher-income White individuals within those groups (DeFilippis, 2018). When these interests are constructed as separate from and even oppositional to the interests of (presumably heterosexual) racial communities, it is queer people of color and their families who are especially harmed (Cahill, 2010; Romero, 2005). Cahill (2010) argues that while antigay groups have constructed LGBTQ rights as "special rights" that threaten the civil liberties of people of color, antigay policies in fact have a disproportionate impact on Black and Latinx same-sex couple families who are more likely to be raising children and to have economic challenges-points we return to later in this chapter.

The study of race is also important within the larger discourses of diversity politics. For example, Hicks (2011) argues that White LGBTQ parents have the privilege to ignore inequalities around race and racism in a way that people of color do not. In his analysis of in-depth interviews with lesbian, gay, and queer parents, Hicks describes one White gay father who claimed that race was a "nonissue" for him and his two adopted Vietnamese sons. However, Hicks notes that this White father could not possibly know all the ways his sons will be positioned racially by others. The literature we review rejects a colorblind view of race as a "nonissue" for parents and families and instead acknowledges the significance of race, ethnicity, citizenship, and colonial legacies in queer family formation.

Conversations about how best to integrate intersectionality frameworks with queer theory have also come to bear on family studies (see Few-Demo, Humble, Curran, \& Llyod, 2016). Allen and Mendez (2018) find that efforts to decenter heteronormativity in family studies often do not address the racialized contexts in which families are situated. Acosta (2018) argues that a "queerer" family scholarship is possible 
when we theorize in the flesh and from the borderlands, connecting with material realities and attending to race in our work. Allen and Mendez, Acosta, and other scholars working at the intersections of race and sexuality hold that queer theories will be strongest when they are raceconscious and mindful of how these constructs shape people's real lives.

The chapter begins with demographic characteristics of racially and ethnically diverse LGBTQ parents in North America and structural inequalities that emerge as salient for these groups. We next examine racial variation in how LGBTQ people become parents and navigate the gendered institutions of motherhood and fatherhood. While our focus is on families of color, we include studies of race and ethnicity in the lives of White lesbians and gay men who become parents through transracial adoption or surrogacy. The global reach of the surrogacy industry (see chapter "Gay Men and Surrogacy") underscores the need for studies that do not conceptualize the intersections of race and sexuality solely through the lens of US history and culture. As Purkayastha (2012) argues, a more robust intersectionality theory is possible when we look beyond Euro-American societies and attend to axes such as race within, between, and across nation-states. We offer a small step in this direction by engaging with studies of LGBTQ-parent families in geographic and cultural contexts that have received less scholarly attention. Throughout the chapter, we discuss ways to decenter assumptions about LGBTQ parenthood and approaches to this field of study that implicitly privilege White, North American families.

\section{Portrait of LGBTQ Parents of Color: Demographic Characteristics and Structural Inequalities}

Census and other survey data point to consistently high rates of parenting among queer and trans people of color. Among the 6450 trans and gender nonconforming people who took part in the National Transgender Discrimination Survey (NTDS), American Indian respondents were the most likely to have children (45\%) followed by respondents who are Latinx (40\%), White (40\%), Black (36\%), multiracial (29\%), and Asian (18\%) (Stotzer, Herman, \& Hasenbush, 2014). Among same-sex couples (and same-sex couples may include trans and gender nonconforming people), $41 \%$ of women of color and $20 \%$ of men of color have children under 18 in the home; for White women and men, these estimates are $23 \%$ and $8 \%$, respectively (Gates, 2013b). As of the 2010 US census (the most recent census data available as of this review), 34\% of African American, $29 \%$ of Latinx, and 26\% of Asian American same-sex couples report that they are raising children (Kastanis \& Gates, 2013a, 2013b, 2013c). These families tend not to be clustered in areas with proportionately large numbers of LGBTQ residents. Instead, they are most likely to reside in cities, towns, and rural areas with other members of their racial and ethnic communities (Kastanis \& Gates, 2013a, 2013b, 2013c; see Battle et al., 2017a, 2017b; Pastrana et al., 2017). Efforts to support LGBTQ parents and their children must be attentive to the broader racial and ethnic communities of which they are a part.

Racially unjust systems-including economic, social, legal, healthcare, and immigration systems - shape LGBTQ parenting possibilities and practices for people of color as well as for Whites who are racially privileged within these systems. Numerous studies show that among same-sex couples, those who are Black, Latinx, Native American, and/or recent immigrants are more likely to be poor, less likely to own their homes, and more likely to lack health insurance compared to those who are White and native born (DeFilippis, 2016). Thirty-eight percent of Black children in households headed by two women and $52 \%$ in households headed by two men are living in poverty, the highest poverty rate of any group (Badgett, Durso, \& Schneebaum, 2017). The 2015 US Transgender Survey reveals greater vulnerability among trans people of color to housing insecurity and homelessness, job loss, unemployment, police harassment, and imprisonment (James, Brown, \& Wilson, 2017; James, Jackson, \& Jim, 2017; James \& Magpantay, 2017; James \& Salcedo, 2017). Among families 
that include children, each of these vulnerabilities has lasting implications for the adult's ability to parent effectively and for the children witnessing the unequal treatment of their parents. Similarly, in a statewide needs assessment of LGBTQI (lesbian, gay, bisexual, transgender, queer, and intersex) people in Hawai' $i$, Native Hawaiians reported more discrimination based on gender identity/expression and sexual orientation compared to other groups (Stotzer, 2013). While not disaggregated by parental status, many of the areas where this discrimination and poor treatment occurred, such as in social service settings, are relevant to parents and children who are disproportionately likely to need such services.

The racism that is prevalent at all levels of the criminal legal system in the USA has direct and deleterious effects on LGBTQ parents of color who come into contact with the courts and the law. For example, among trans people who have separated from a partner or spouse, $29 \%$ of Black parents report that courts or judges have limited or terminated their relationships with their children on the basis of their transgender identity or gender nonconformity; the same is true for $20 \%$ of multiracial, $17 \%$ of American Indian, $12 \%$ of White, and 9\% of Latinx NTDS respondents (Grant et al., 2011; of note is that the Asian sample size for this question was too low to report). Such decisions unjustly sever parent-child bonds, with lasting consequences for these children and families (see Lens, 2019; Roberts, 2009).

The healthcare system is another site of struggle for many trans parents and prospective parents, with implications for parent and child wellness and for trans people's pathways to parenthood. Nixon (2013) argues that sterilization requirements for sex reassignment and discrimination at multiple levels of the healthcare system-from insurance to fertility preservation and other reproductive options-result in passive eugenics for trans populations. She notes that in the USA, eugenics ideologies have historically taken three forms: immigration restrictions that target specific racial groups, anti-miscegenation laws, and coercive sterilization of "people deemed unfit to reproduce," overwhelmingly people with disabilities and women of color
(Nixon, 2013, p. 81). This legacy of racialized eugenics practices informs and intersects with trans-specific eugenics discourses to impinge on the reproductive autonomy of trans people of color.

Immigration policies and practices matter to LGBTQ-parent families as well. Researchers estimate that LGBTQ people comprise $2.4 \%$ of adult immigrants who are documented and $2.7 \%$ of adult immigrants who are undocumented in the USA, and parenthood is prevalent among these groups (Gates, 2013a). Twenty-five percent of binational same-sex couples and $58 \%$ of samesex couples that include two noncitizen partners have children under 18. Among all Latinx samesex couples raising children, 1 in 3 include at least one noncitizen partner (Kastanis \& Gates, 2013b). The same is true for 1 in 4 Asian and Pacific Islander same-sex couples raising children (Kastanis \& Gates, 2013a). Approximately 75,000 LGBTQ people qualify for the Development, Relief, and Education for Alien Minors (DREAM) Act and 36,000 have participated in Deferred Action for Child Arrivals (DACA) (Conran \& Brown, 2017). We do not currently have data on how many DREAMers and DACA recipients have children, but we do know that immigration policies have a significant impact on parent and child well-being (Androff, Ayon, Becerra, Gurrola, \& Salas, 2011; Dreby, 2015), and this is certainly true for LGBTQ parents and children in these communities. In a nationwide survey of Asian and Pacific Islander (API) LGBT Americans, respondents ranked immigration as the number one issue facing all APIs in the USA and one of the top four issues facing API LGBT Americans (Dang \& Vianney, 2007).

Prior to 2013, same-sex couples were excluded from family unification under federal law (Cianciotto, 2005; Romero, 2005). US Supreme Court decisions to strike down the Defense of Marriage Act (DOMA) and to legalize same-sex marriage nationwide have since opened pathways to citizenship and increased security for some binational couples and their children. However, it is important to recognize that the US immigration system remains oppressive to many and that 
in an era of heightened White nationalism, LGBTQ parents and children of color who immigrate to the USA, or arrive seeking refugee or asylee status, continue to face exclusion, forced separation, and other forms of violence that are not remedied by legal same-sex marriage (Brandzel, 2016; Chávez, 2013).

\section{Gaps in Our Knowledge and Areas for Future Research}

\section{Family Resilience}

Amid pervasive discrimination in social institutions and interactions, LGBTQ people of color also exhibit unique parenting strengths. For example, Asian, Black, and Latinx trans people report greater improvement in parent-child relationships after coming out and lower rates of rejection by their children than do White trans people (Grant et al., 2011). This points to the quality of parental bonds between trans parents of color and their children as an important area for researchers to explore. LGBTQ parents of color are more likely to report that they are supported by their extended families, while rejection by blood relatives after coming out is more common among White LGBTQ parents (National Black Justice Coalition, 2012). Such findings challenge the assumption that LGBTQ people of color are more likely to be rejected by their families due to intersections of race and religiosity and related culturalist and often racist assumptions that communities of color are "more homophobic" (see Han, 2015, 2017). Increased focus on community strengths and assets will help to counter the deficit model that persists in research on LGBTQ families and families of color (Akerlund \& Cheung, 2000; Prendergast \& MacPhee, 2018).

\section{Gaps in Census and Other Survey Data}

North American census data remain limited in ways that are directly linked to issues of race, ethnicity, and sexuality. Most of the demographic data on LGBTQ families of color in Canada are found in the context of health (Balsam, Molina, Beadnell, Simoni, \& Walters, 2011; Ross, Epstein, Goldfinger, Steele, Anderson, \& Strike, 2014). Little is available on parenting, parenthood, or even family structures and compositions. One of the reasons for the paucity of data on race and LGBTQ families in Canada may be the abolition of the long-form census by the conservative government between 2010 and 2015. Justin Trudeau reintroduced the longform in the 2016 census, but the data from the longform are still being collated. In the USA, we lack information about Middle Eastern and North African LGBTQ people, who are racialized in US society (Hakim, Molina, \& Branscombe, 2017; Strmic-Pawl, Jackson, \& Garner, 2018). Data on American Indian and Alaskan Native (AIAN) populations remain slim (see Goldberg \& Conron, 2018 for preliminary estimates of LGBTQ AIAN adults by region). In addition, counting only samesex couple-headed households excludes single LGBTQ parents and other family arrangements (Battle et al., 2017a; Compton \& Baumle, 2018). Efforts are underway to "queer the census," to include a Middle Eastern and North African (MENA) option, and to further refine the census around issues of race, ethnicity, and sexuality in ways that may expand research possibilities. ${ }^{3}$ At the same time, some scholars have drawn attention to the White supremacist and eugenicist roots of counting populations and have raised questions about the implications of doing so in this political moment (Spade \& Rohlfs, 2016; Strmic-Pawl et al., 2018). Our calls for better census and survey data must be carefully balanced with a critical eye toward how and by whom these data are used.

\section{Multiracial Families}

Compared to different-sex couples, same-sex couples are more likely to be interracial or interethnic and more likely to create families that

\footnotetext{
${ }^{3}$ See examples of these campaigns here http://www.thetaskforce.org/thanks-for-keeping-the-census-queer/ (retrieved September 8, 2018) and here http://www.aaiusa.org/2020census (retrieved September 8, 2018).
} 
include parents and children from different racial and ethnic backgrounds (Kastanis \& Wilson, 2014). Eighty percent of Asian and Pacific Islander, $63 \%$ of Latinx, and $47 \%$ of African American individuals who are part of a same-sex couple have a partner of a different race or ethnicity (Kastanis \& Gates, 2013a, 2013b, 2013c). Yet even discourses at the intersections of race and sexuality often fail to acknowledge these families. For example, many analyses of samesex couples raising children follow the census approach of categorizing families by the race of the head of household. Multiracial households are not visible in this framework.

In recent years, qualitative researchers have brought multiracial families into focus. Acosta (2013) analyzed the ways that sexually nonconforming Latinas navigate their interracial and interethnic relationships, including relationships with other women of color who share a mestiza consciousness but are differentially positioned within US racial hierarchies. Although her 42 study participants did not automatically experience power imbalances based on gender, they did have to navigate imbalances based on race, language, and citizenship status. Some participants experienced conflict with families of origin over their partners' race and culture-an important reminder that LGBTQ family issues do not concern gender and sexuality only. These negotiations inform many dimensions of family life, including parenting practices and experiences. Karpman et al. (2018) found that lesbian, bisexual, and queer women of color who became parents in the context of an interracial partnership ( $n=11$ of 13 couples interviewed) were thoughtful about the racial characteristics the child would share with each mother. LBQ women of color in this study were attuned to issues surrounding transracial adoption and parenting - which is discussed in a later section of this chapter-and they brought this into their decision-making about donor selection and adoption.

In an interview with psychologist Sekneh Beckett, Alyena Mohummadally discussed her experiences as a Pakistani, Australian, queer Muslim who is also a mother (Beckett, Mohummadally, \& Pallotta-Chiarolli, 2014).
Mohummadally has chosen to raise her child as a Muslim in the context of her interethnic and interfaith relationship. Her partner, a White Australian woman, had initial concerns about this decision but became supportive after learning more about Islam and about Mohummadally's family life; both women agree that raising their son as a Muslim "just feels right" (Beckett et al., 2014; Mohummadally, 2012, p. 1). Such negotiations are not unique to same-sex couples but may be uniquely inflected by intersections of sexuality and gender with ethnicity, faith, and culture. Same-sex couples may, for instance, have additional obstacles to overcome in finding a faith community that welcomes their family as one that is both interethnic and queer. As we learn more about multiracial families in general, it is important that we include LGBTQ parents and their children, who are disproportionately likely to be a part of such families.

\section{Pathways to Parenting}

\section{Parenting Children from a Prior Heterosexual Relationship}

The best available data suggest that a large percentage of queer parents had their children in the context of a prior heterosexual relationship and that this pathway to parenting is most common among queer people of color (Tasker \& Rensten, 2019). Many researchers have framed their studies of lesbian and gay parenthood to make their results comparable to those of other empirical studies of family structure and family process in heterosexual two-parent families. Such an analogous research design makes it easier to test central assumptions in the literature regarding the division of household labor and the distribution of childcare and childrearing tasks, for example (Compton \& Baumle, 2018). Research on lesbian-headed families also tends to be framed around long held assumptions about lesbian identity, particularly the idea that lesbians as a group are egalitarian in their distribution of paid work, housework, and childcare and that they organize their households and interact with each other in 
ways that support this principle (Dunne, 2000; Sullivan, 2004). Unfortunately, restricting samples so that they only include women who take on a lesbian identity before becoming parents overrepresents White middle- and upper-income lesbians, who are more likely to support the ideological principles of feminism and who are better able to afford costly insemination procedures (Moore, 2011a).

In her three-year, mixed-methods study of African American lesbian families, Moore (2011a) found that many lesbian women who had become mothers in the context of a prior heterosexual union continued to make a concentrated effort to satisfy the societal definition of a "good mother" that is implicitly linked to heterosexuality. This expectation produced a conflict for lesbian mothers, who had to contend not only with the construction of lesbian identity as deviant, but also with negative stereotypes around race and Black women's sexuality. Their sexual orientation forced a sexual self into visibility in the context of motherhood, which frightened some and went against a politics of silence in this arena. ${ }^{4}$ While lesbian mothers across racial groups may struggle to be viewed as "good mothers," the standards to which they are held are shaped not only by constructions of gender and sexuality, but also by constructions of race, racism, and intraracial group dynamics.

Gay and bisexual men who become fathers through their heterosexual relationships face similar pressures. In the largest qualitative study to date of sexuality and migration, comprising indepth interviews with 150 Mexican-origin and Latinx gay and bisexual men and their partners, Carrillo (2018) identifies fatherhood as one of many factors shaping the men's immigration trajectories. This is evident in the life story of a study participant, Cuauhtémoc, who became a father through heterosexual marriage and migrated to the USA primarily to provide for his wife and children financially. He maintained this role as a provider to his family at the same time that he formed sexual and romantic relationships

${ }^{4}$ For more information on the politics of silence, see Hammonds, 1997. with men in San Diego and gradually developed a bisexual identity. Contrary to normative expectations about "coming out," Cuauhtémoc continued to value his life as a straight-identified husband and father in Mexico, keeping his family circle carefully separated from his gay, bisexual, and transgender friendships and relationships in San Diego. Carrillo notes that men in the study were able to craft new lives in the USA while also maintaining what they liked about their lives in Mexico. Their journeys were not from "traditional" to "modern" modes of sexuality; Mexico has its own versions of sexual modernity and the men in the study are participants, not objects, in processes of sexual globalization. A simplistic reading of Cuauhtémoc's life might cast him as a "closeted" bisexual man. However, the portrait that emerges from Carrillo's research is far more complex. Such critical and compassionate research is needed to bring light to the largely invisible experiences of men who balance the expectations of heterosexual fatherhood with their bisexual and gay identities and lives.

\section{Parenting in Extended Families and Communities}

In many racial and ethnic communities, family responsibilities, including the provision of financial and emotional support, elder and child caretaking, and other household duties are shared throughout social networks that may involve extended family and friends' participation in a variety of familial roles (Cross, 2018). Research on Black families has shown that kinship arrangements commonly include multigenerational family structures as well as other types of extended family households (Moras, Shehan, \& Berardo, 2007). Several researchers have found that Latinx, Asian, and Caribbean immigrant families sustain complex networks that join households and communities, even across geographic borders, to provide assistance and support after immigration (e.g., Menjívar, Abrego, \& Schmalzbauer, 2016; Taylor, Forsythe-Brown, Lincoln, \& Chatters, 2015). LGBTQ people are also a part of these multigenerational and extended family networks. 
In addition to parenting their own biological, foster, and adopted children, many queer people provide financial and emotional support to siblings, nieces and nephews, and grandchildren and to other children within their racial and ethnic communities (Mays, Chatters, Cochran, \& Mackness, 1998; Moore, 2011a). Black same-sex couples are more than twice as likely as White same-sex couples to be parenting at least one nonbiological child, including children of relatives (Moore \& Stambolis-Ruhstorfer, 2013). These parenting and family arrangements often do not show up in research studies that define same-sex parenting more narrowly.

Gilley (2006) spent 6 years living and working with members of two southwestern organizations for Native people who identify themselves as Two-Spirit. His work explores many dimensions of what it means for contemporary Indian people to "become" Two-Spirit through a synthesis of male and female qualities and gay and Native identities. Gilley's informants explained that Two-Spirit people have historically had caregiving roles, teaching children (especially girls) about Indian ceremonies and other cultural practices and caring for children when their parents are unable to do so. Two-Spirit men in the study cared for nieces, nephews, and other family members, supervised organizations for local teens, and reached out in formal and informal ways to support gay Indian youth. In keeping with their Two-Spirit identity, the men were called upon to stand in as both male and female role models for young people. The men did not describe their parenting activities in terms of a personal desire to have children or form a nuclear family together with a same-sex partner. Instead, their parenting roles were largely indistinguishable from their obligations to the larger family, community, and tribe. By teaching children and youth about Indian culture, Two-Spirit people positioned themselves as integral to Indian life (Gilley, 2006). Other researchers working with Two-Spirit populations that are diverse in terms of tribe, culture, and region have reported similar findings regarding caregiving roles (EvansCampbell, Fredriksen-Goldsen, Walters, \& Stately, 2007).
A second example of parenting to sustain the community emerges from Lewin's (2009) research on gay fathers. Drawing from interviews with 95 gay fathers in four metropolitan areas, Lewin analyzes the meanings gay men attach to their parenting roles and aspirations as they move across spaces defined as "gay" and those related to family and thus "not gay" by conventional standards. Among other meaningmaking strategies, gay men in this research constructed fatherhood as the right thing to do in moral terms, often in response to stereotypes of gay men as morally deficient. For Black gay men, the moral impetus for fatherhood took on a special urgency, framed as a responsibility that extended beyond their immediate circle of kin. Non-Black men also described fatherhood as "doing the right thing," but for Black fathers this included doing the right thing for the racial community by caring for Black children who might otherwise languish in the foster care system. Lewin's research shows the salience of race even in patterns that occur across racial groups. While racially and ethnically diverse gay men used similar narrative constructs to describe their parenting, these took on different contours for Black gay fathers, who were most likely to connect their parenting narratives to larger issues of systemic racism and the survival of Black children.

\section{Transracial Adoption and Surrogacy}

As the numbers of LGBTQ-parent families increase, so do the numbers of White LGBTQ parents raising children of color (Farr \& Patterson, 2009; Goldberg, 2019). Lesbian and gay people are more likely than heterosexual people to adopt a child of a different race or ethnicity (Brooks, Whitsett, \& Goldbach, 2016; Goldberg, Sweeney, Black, \& Moyer, 2016). Substantial research makes it clear that race and color consciousness, not "color blindness," is the best practice approach to transracial adoption (e.g., Fong \& McRoy, 2016; Quiroz, 2007; Wyman-Battalen, Dow-Fleisner, Brodzinsky, \& McRoy, 2019). Thus, White LGBTQ parents who adopt children 
of color need to be prepared to engage with issues of race and racial inequality.

Goldberg et al. (2016) examined approaches to racial socialization among 82 lesbian, gay, and heterosexual adoptive parents, a majority of whom were White and raising children of color. Consistent with prior research, about one-half of these parents engaged actively in racial socialization, about one-third did so but more cautiously, and a smaller group of parents avoided addressing race in their families. Lesbian and gay adoptive parents were less likely to use an avoidant approach, more likely to engage in "positive race talk," and more likely to prioritize ties with communities of color compared to heterosexual parents in the study. The authors connect these qualities to parents' own experiences of difference as a source of pride, identity, and community (Goldberg et al., 2016; see Goldberg \& Smith, 2016). In a later analysis of school decision-making among lesbian and gay adoptive parents, Goldberg and colleagues (2018) find that while all parents juggled children's intersecting identities, lesbian mothers placed greater emphasis on a racially diverse school environment to enhance their child's racial identity and sense of self. This work highlights additional dimensions of gender and class in racial socialization and race consciousness among adoptive parents.

Hicks (2011) argues that transracial adoption by lesbian, gay, and queer parents forces scholars to consider how race is related to ideas about resemblance and belonging-what it means to "look like" family. In interviews with lesbian adoptive couples creating multiracial families, Hicks analyzes the importance to many of these mothers of "looking like" a family with regard to skin color, often in anticipation of how their family will be perceived by others. While lesbian and gay parenting may destabilize notions of racial inheritance and biological bonds and while some parents explicitly challenge these ideals, they should also be aware of ways that racism may be expressed through insistence upon likeness as a criterion for family formation. Researchers have made similar observations in studies of sperm donor selection among lesbian couples (Andreassen, 2019; Ryan \& Moras, 2017) and surrogacy arrangements among gay men (Berkowitz, 2013; Ryan \& Berkowitz, 2009). Such desires and demands among White lesbian and gay prospective parents show the hegemonic power of fitting into what Pyke (2000) calls the normal American family and Smith (1993) calls the standard North American family - a heteronormative, classed, and racialized ideology of what a family ought to be.

There is a paucity of statistical data on the numbers of LGBTQ-parent families who use surrogacy as way to have children. A small but growing number of research studies suggest that surrogacy has become a particularly popular pathway to parenthood for cisgender gay men (Patterson \& Tornello, 2010) and that most of the gay men who access surrogacy are White and wealthy (see chapter "Gay Men and Surrogacy"). Surrogacy has produced a new layer of racialized, gendered, classed, and colonial stratification on a global level (DasGupta \& DasGupta, 2010; Gondouin, 2012; Nebeling Petersen, 2018; Pande, 2015; Rudrappa \& Collins, 2015; Vora, 2012). While many gay men work with altruistic surrogates (i.e., surrogates who do not receive monetary compensation), commercial surrogacy is fast becoming a common feminized vocation (Jacobson, 2016). Given the high cost of surrogacy in the West, many people, including gay men who want to pursue surrogacy, are turning to the Global South due to its lax laws and large supply of what Pande (2015) calls the "perfect surrogate — cheap, docile, selfless, and nurturing" (p. 970).

In their interviews with gay men from the USA and Australia who had availed commercial surrogacy services in India, Rudrappa and Collins (2015) found that men used "strategic moral frames" of surrogates' financial empowerment, access to reproductive rights, and liberation from patriarchy as justification for surrogacy. But the authors' interviews with the surrogates reveal how these moral frames were systematically created by the multimillion-dollar surrogacy industry by maintaining a commercial distance between the surrogate mothers and their Western clients. This distance maintained the surrogate mothers as singular monolithic "third-world" 
subjects (Mohanty, 1984), who are poor, shy but loving, ready to serve and fulfill the dreams of childless parents, and in need of rescue from their impoverished conditions by White men. The binaries created between the clients and the surrogates produced a classed and racialized image of the surrogate and a benevolent and wealthy image of Western clients who needed the surrogates to fulfill a familial dream. These images made the commercial exchange of intimate reproductive labor seamless while maintaining power hierarchies and keeping global inequalities intact.

\section{LGBTQ-Parent Families Beyond North America}

We have noted in several places that global exchanges and inequities matter for LGBTQ parents and their children. Euro-American perspectives, while important, do not represent the experiences and interests of a majority of the world's families. In this final section, we turn our attention to studies of sexually nonconforming parents and prospective parents in Suriname, urban China, Tunisia, Chile, rural India, South Africa, Taiwan, and New Zealand indigenous communities. We present these eight cases (illustrative of a much larger body of international work) to highlight the rich variation in ways that heteronormative definitions of family are constructed and contested and theoretical implications that emerge from this variation.

\section{Rethinking the Distinction Between "Heterosexual" and "Same- Sex" Parent Families}

It is common within family scholarship to classify couples and households as either "heterosexual" or "same-sex." Such a typology enables researchers to compare outcomes for children raised in these households and to make arguments about the unique strengths or deficits of same-sex-parent families. However, this is often an artificial distinction and one that has limited the scope of LGBTQ family research in many parts of the world.

Wekker's (2006) ethnographic research on women engaged in "the mati work" in Paramaribo, Suriname, is instructive with regard to the limits of the heterosexual/same-sex-parent typology. Mati refers to love and sexual intimacy between women, conceived of as a pleasing behavior rather than as the basis of an individual or collective identity. Wekker found that women who mati usually have children by men and maintain sexual relationships with the fathers of their children, often in exchange for men's financial contributions to their households. Their primary emotional and romantic attachments, however, are to other women and most rely on the help of other women to bring up their children. Wekker uses the case of Afro-Surinamese women who mati to expose the limits of the Western concept of homosexual identity. We use it here to show the limits of the concept of same-sex parenting. Women who mati actively parent with other women and find sexual and romantic fulfillment in these relationships. However, they do not adopt a lesbian identity or see themselves as belonging to a community based on their sexual object choice, nor do they necessarily discontinue all sexual relations with men. Wekker's findings are consistent with reports that in African and other non-Western societies, women who are engaged in same-sex relationships may have men to fulfill certain functions, one of them being to reproduce (Aarmo, 1999; Potgieter, 2003). Conventional definitions of lesbian parenting that focus on the same-sex couple do not account for these kinds of arrangements.

Throughout the world, many people who have same-sex relationships enter or remain in concurrent heterosexual marriages (recall Cuauhtémoc, the father in Carrillo's, 2018 study discussed earlier in this chapter, as another illustration of this practice carried out across borders). Engebretsen (2009) presents three case studies to highlight a range of lala (lesbian) family arrangements in Beijing, China. One woman remained heterosexually married and mothered a child in the context of this marriage while also dating her lala partner. Two other lalas created a marriage-like relation- 
ship with one another and merged families, sharing care work for elderly parents. In the third case, a self-identified chunde $T$ (pure T; similar, though not equivalent, to stone butch) chose to marry a gay male friend to satisfy her parents. Those who married men were able to maintain what Engebretsen calls "hetero-marital face," but found it difficult to form and keep lasting samesex relationships because of the demands their marital and family arrangements placed on them. The women who formed a marriage-like relationship with one another found more lasting satisfaction in that relationship but expressed deep regret at their inability to have a child together. Engebretsen does not conclude that any one of these family arrangements is superior to or ultimately more satisfying than the others. Instead, she critiques Western discourses that prioritize certain marital ideologies and relationship strategies, without fully recognizing the diversity of nonnormative sexualities globally.

In contexts where gay sexuality is prohibited and/or where assisted reproductive technologies and adoption services are only available to heterosexually married couples, heterosexual marriage remains the planned pathway to parenthood for many LGBTQ people. Hamdi, Lachheb, and Anderson (2018) conducted cyber interviews with 28 gay Muslim men living in Tunisia; while the interviews focus on the integration of religion and sexuality, plans for marriage and fatherhood also surface in the men's narratives. Those who hope or plan to become fathers expect to do so through marriage to a woman. As one interviewee shared: "I did not choose homosexuality, and I would like to get married [to a woman] one day and have children, even though I cannot imagine myself with a woman on a bed" (Hamdi, Lachheb, \& Anderson, 2018, p. 1301). Another man compromised by looking for a lesbian to marry, not unlike the chunde $T$ interviewed by Engebretsen (2009); for other examples of gay-lesbian marriages in Taiwan, Korea, and China, see Brainer, 2019; Cho, 2009; and Huang \& Brouwer, 2018, respectively).

Rearing a child conceived within a heterosexual marriage can carry some unique challenges and costs. Child custody is a particularly high stakes area for LGBTQ people who became parents in this way and whose marriages later end. Herrera (2009) identified this issue in her fieldwork and interviews with 29 Chilean lesbian women. Many of the women hid their sexual orientation from their families and especially from their ex-husbands because they feared losing custody of their children. These women saw their motherhood and their lesbian identities and relationships as compatible, yet recognized that they would be viewed and treated as "bad mothers" within the court system because of their sexuality. Herrera noted that a legitimate fear of having one's children taken away "profoundly marks the way [Chilean lesbians] experience motherhood" (p. 50).

By classifying households as either heterosexual or same-sex, researchers exclude those households where parenting arrangements are shared among multiple adults who may be romantically and/or sexually connected to one another. This classification does not prepare us to recognize and support LGBTQ parents who are balancing more traditional or traditional-seeming marriages with their nonnormative identities and relationships and who may face particularly difficult custody battles if and when those marriages dissolve. Studies by Wekker (2006), Carrillo (2018), Engebretsen (2009), Hamdi, Lachheb, and Anderson (2018), Herrera (2009), and other scholars working in diverse geographic and social locations require family scholars to think more broadly about what queer parenting might look like and the issues that these families face.

\section{Alternatives to a Politics of "Sameness"}

A central feature of the same-sex/heterosexual parent typology is the ability to compare and contrast these households, often to counter (or in some cases, bolster) political claims that heterosexual parenting is superior and should be uniquely protected. Several scholars have pointed out that basing LGBTQ parents' rights on claims that they are the same as heterosexual parents is methodologically and epistemologically flawed 
(e.g., Berkowitz, 2009; Carroll, 2018b; Dozier, 2015). Moreover, queer and trans people do not necessarily see heterosexuals raising children as the model or gold standard for parenting. Many LGBTQ parents make conscious choices to parent in ways that differ from other members of their communities and to pursue countercultural goals for their children's futures.

One such example is offered by Swarr and Nagar (2003) in their case analysis of a masculinefeminine female couple raising two daughters in rural India. The couple chose not to arrange marriages for their daughters despite family and community pressure to do so. These mothers explained that they wanted their daughters to receive an inheritance so that they would have the option not to marry. For a similar reason, they chose not to follow social convention by adopting a son, as the son would then have rights to all they owned. The mothers connected their vision for their daughters' inheritance rights and future independence to their own struggles for independence from compulsory heterosexual marriage. In doing so, they voiced a desire to make the institutions of marriage and family fairer for sexually nonconforming people and for women.

Another pointed critique of family as a heteronormative institution appears in Lynch and Morison's (2016) analysis of media discourses about gay fathers and their children in South Africa. The range of discourses Lynch and Morison describe make it clear that normalizing strategies, including efforts to downplay or deny differences between gay and heterosexual parents, remain quite common in South African media. But more resistant talk is also present, constructing queer parents as different in positive and desirable ways and challenging the heteronormative "gold standard." For example, in response to a government document that presented the heterosexual nuclear family as inherently nurturing and supportive, one commentator wrote,

In reality, many families 'nurture' unequal social relations between men and women, rich and poor, black and white, queer and straight... Women's subordination is reproduced in families where boys are raised to assume masculine dominance and girls are told (most recently by the president) that marriage and child rearing is their primary social role... The [document's] hallowed 'family' is often a pretty unsafe place. (Lynch \& Morison, 2016, pp. 200-201).

Other commentators pointed out that children of gay and lesbian parents may be more tolerant of differences and thus well-adjusted to a multicultural society. Such arguments do not rely on proving that queer parents are "as good as" heterosexual parents or that their family lives will be the same.

Similarly, Brainer's (2019) fieldwork and interviews with LGBTQ people and their families in Taiwan ( $n=47$ LGBTQ people and 33 heterosexual parents and siblings) includes several queer parents who resist the normative gender and family roles that are imposed on their children by others. One $T$ (transmasculine) mother made a series of life-altering decisions after learning that her son is gay, among them ending her 20-year marriage to a man and breaking ties with family members who treated her poorly because of her masculinity. She explained that she did this to shield her son from family pressure and abuse and to encourage her son's relationship with his boyfriend as an alternative to heterosexual marriage. It was her intersecting roles as a $\mathrm{T}$ parent that empowered this mother to reject the social norms surrounding marital and family relationships. Another interviewee supported her adult daughter's polyamorous relationships with men, explaining that her own journey through heterosexual marriage and her developing identity as a la ma (lesbian mother) had altered her expectations for her child. For example, she now prioritized her daughter's sexual autonomy over conformity to cultural scripts. Both mothers described the differences embodied by their children and their support for such differences as evidence of their unique parenting strengths rather than deficits.

Glover, McKree, and Dyall (2009) used focus group interviews to study fertility issues and access to reproductive technologies in Maori (New Zealand indigenous) communities. Among takatapui (nonheterosexual) women interviewed, the issue of sperm donation was discussed at 
length. Some takatapui women reported that they preferred gay male sperm donors because they wanted to limit the influence of heterosexuality on their children and because they wanted to pass on the "gay gene" if such a thing should exist. The significance of these comments becomes more apparent when we consider the social and political climate in New Zealand, where the largest sperm bank banned gay donors until 2006. After the ban was lifted, a Professor of Genetics at New Zealand's Canterbury University said people who received sperm from gay men should be informed that a "gay gene" might be passed to their children (Glover et al., 2009, p. 305). In a context where discourse around the possible existence of a "gay gene" has been used to directly attack queer communities, takatapui mothers and prospective mothers offer a counter-discourse by constructing the "gay gene" as a positive and desirable trait.

Taken together, critiques of the same-sex/heterosexual typology and efforts to prove that these two types of families are virtually the same produce alternative ways to conceptualize the needs, desires, and social roles of LGBTQ parents. Some parents have not constructed a personal or collective identity based on the gender of their sexual partner(s). They have complicated relationships with the institution of marriage and may have heterosexual marriages and same-sex relationships concurrently. Comparative research often assumes structural difference while looking for similarity in child outcomes. Parents in the case studies we have presented seek precisely the opposite. Even as their households may look structurally similar to those of heterosexuals, many have made efforts to instill values and offer opportunities to their children that differ from widely held values in their countries and cultures of origin.

\section{Future Directions for Research and Practice}

Banerjee and Connell (2018) call on social scientists to engage with conceptual work originating in the Global South and under conditions of colonialism and postcolonialism. This shift is not about collecting data in these areas, although that may be a part of the work. Rather, it is about incorporating theoretical insights that disrupt a still very deeply Western-centric canon (see Connell, 2007). Analytic approaches to LGBTQ parenting will be strongest when they shift in the ways that Banerjee and Connell describe. For instance, deploying a "solidarity-based approach" (p. 66) would allow us to analyze how coloniality has shaped LGBTQ parenting in the Global South and the Global North. This shift cautions scholars of the Global North against using the Global South merely as repository of data about LGBTQ parenting. Instead, Banerjee and Connell push us to change our perspectives to consider what we know about LGBTQ parenting in the Global South as a conscious body of knowledge that undoes our hegemonic and colonial understandings of parenting, queer sexuality, and family formations. There is still much that we do not know about queer sexuality and family formation in a majority of the world. The examples in this chapter complicate our understandings of, among other things, who "counts" as a queer or trans parent and what issues matter most to these parents and their children. These do more than diversify our empirical data. New theories and models are required to account for the ways that LGBTQ families are positioned within their societies as well as in global hierarchies.

We urge scholars and practitioners alike to broaden the definition of LGBTQ parenting to account for a greater variety of ways that people create families and bring children into those families. Current definitions exclude some practices that are especially prevalent among LGBTQ people of color, such as parenting children from a prior or ongoing heterosexual union and parenting children within extended family and community networks. We agree with scholars who argue that LGBTQ parenting and related laws and policies are matters of racial and economic justice (see Cahill, Battle, \& Meyer, 2003; Cahill \& Jones, 2001; Cianciotto, 2005; Dang \& Frazer, 2004; DeFilippis, 2018; Schneebaum \& Badgett, 2018). The work we have reviewed provides empirical support for intersectionality theories that challenge scholars 
to move beyond additive models of structural location. Experiences of LGBTQ families of color are not reducible to theories of race and racism, nor to theories of sexuality and heterosexism. It is imperative that we consider the racial implications of laws and policies around same-sex parenting and the implications for LGBTQ parents and children of structural racism and xenophobia.

Expanding research beyond predominately White, Western populations brings a fresh lens to ongoing conversations within LGBTQ family studies. Many of these parents challenge heteronormativity in deeper ways than a politics of sameness can accomplish. The construct of a "good mother" (and, in a smaller number of cases, a good father who "does the right thing") is one that came up in several of the studies we reviewed among parents of different racial and ethnic backgrounds (e.g., Herrera, 2009; Lewin, 2009; Moore, 2011a). But the ways that people think about and try to manifest "good" parenting - or are excluded from this category on the basis of their sexuality - vary by race, class, and other aspects of the parent's social location. As we have noted, even patterns that cut across racial groups often reveal meaningful variation that calls for different kinds of support.

Scholarship on race and ethnicity in the lives of LGBTQ parents and their children has grown substantially and LGBTQ scholars have made strides in centering parents and families of color. At the same time, there are many areas for growth. Transgender and especially bisexual parents of color are often lumped into studies of "LGBT" parents that focus on lesbians and gays see chapters "What Do We Now Know About Bisexual Parenting? A Continuing Call for Research", and "Transgender-Parent Families"). Multiracial families continue to be underrepresented in the literature despite their significant presence in our LGBTQ communities. When LGBTQ families are represented in popular culture and news media, it is still a White, wealthy lesbian or gay couple that is most common (Cavalcante, 2015; Ventura, Rodríguez-Polo, \& Roca-Cuberes, 2019). It is important to get research about the diversity of LGBTQ families out of the academy and into the broader society. Finally, we hope that future work will continue to move beyond a deficit model, attending to the challenges, strengths, and joys of LGBTQ families of color in all their complexity.

\section{References}

Aarmo, M. (1999). How homosexuality became 'unAfrican': The case of Zimbabwe. In E. Blackwood \& S. Wieringa (Eds.), Female desires: Same-sex relations and transgender practices across cultures (pp. 255-280). New York, NY: Columbia University Press.

Acosta, K. (2013). Amiga y amantes: Sexually nonconforming Latinas negotiate family. New Brunswick, NJ: Rutgers University Press.

Acosta, K. (2018). Queering family scholarship: Theorizing from the borderlands. Journal of Family Theory \& Review, 10, 406-418. https://doi. org/10.1111/jftr. 12263

Akerlund, M., \& Cheung, M. (2000). Teaching beyond the deficit model: Gay and lesbian issues among African Americans, Latinos, and Asian Americans. Journal of Social Work Education, 36, 279-292. https://doi.org/1 0.1080/10437797.2000.10779008

Alimahomed, S. (2010). Thinking outside the rainbow: Women of color redefining queer politics and identity. Social Identities, 16, 151-168. https://doi. org/10.1080/13504631003688849

Allen, S., \& Mendez, S. (2018). Hegemonic heteronormativity: Toward a new era of queer family theory. Journal of Family Theory \& Review, 10, 70-86. https:// doi.org/10.1111/jftr.12241

Androff, D., Ayon, C., Becerra, D., Gurrola, M., Salas, L., Krysik, J. Gerdes, K., \& Segal, E. (2011). U.S. immigration policy and immigrant children's well-being: The impact of policy shifts. Journal of Sociology \& Social Welfare, 38, 77-98. https://scholarworks. wmich.edu/jssw/vol38/iss 1/5

Andreassen, R. (2019). Mediated kinship: Gender, race, and sexuality in donor families. New York, NY: Routledge.

Badgett, M. V. L., Durso, L., \& Schneebaum, A. (2017). New patterns of poverty in the lesbian, gay, and bisexual community. Los Angeles, CA: The Williams Institute, UCLA School of Law.

Balsam, K. F., Molina, Y., Beadnell, B., Simoni, J., \& Walters, K. (2011). Measuring multiple minority stress: The LGBT people of color microaggressions scale. Cultural Diversity and Ethnic Minority Psychology, 17, 163-174. https://doi.org/10.1037/ a0023244

Banerjee, P., \& Connell, R. (2018). Gender theory as southern theory. In B. Risman \& W. Scarborough (Eds.), Handbook of the sociology of gender (pp. 57-68). New York, NY: Springer. 
Battle, J., Pastrana, A., \& Harris, A. (2017a). An examination of Asian and Pacific Islander LGBT populations across the United States: Intersections of race and sexuality. New York, NY: Palgrave Macmillan.

Battle, J., Pastrana, A., \& Harris, A. (2017b). An examination of Black LGBT populations across the United States: Intersections of race and sexuality. New York, NY: Palgrave Macmillan.

Beckett, S., Mohummadally, A., \& Pallotta-Chiarolli, M. (2014). Living the rainbow: 'Queerying' Muslim identities. In A. W. Ata (Ed.), Education integration challenges: The case of Australian Muslims (pp. 96-106). Melbourne, Australia: David Lovell Publishing.

Berkowitz, D. (2009). Theorizing lesbian and gay parenting: Past, present, and future scholarship. Journal of Family Theory \& Review, 1, 117-132. https://doi.org/1 0.1111/j.1756-2589.2009.00017

Berkowitz D. (2013). Gay men and surrogacy. In A. Goldberg \& K. Allen (Eds.), LGBT-parent families (pp. 71-85). New York, NY: Springer. https://doi. org/10.1007/978-1-4614-4556-2_5

Bible, J., Bermea, A., van Eeden-Moorefield, B., Benson, K., \& Few-Demo, A. (2018). A content analysis of the first decade of the Journal of GLBT Family Studies. Journal of GLBT Family Studies, 14, 337-355. https:// doi.org/10.1080/1550428X.2017.1349626

Boston, J., \& Duyvendak, J. W. (2015). People of color mobilization in LGBT movements in the Netherlands and the United States. In D. Paternotte \& M. Tremblay (Eds.), The Ashgate research companion to lesbian and gay activism (pp. 135-148). New York, NY: Routledge.

Brainer, A. (2019). Queer kinship and family change in Taiwan. New Brunswick, NJ: Rutgers University Press.

Brandzel, A. (2016). Against citizenship: The violence of the normative. Urbana, IL: University of Illinois Press.

Brooks, D., Whitsett, D., \& Goldbach, J. (2016). Interculturally competent practice with gay and lesbian families. In R. Fong \& R. McRoy (Eds.), Transracial and intercountry adoption: Cultural guidance for professionals (pp. 90-125). New York, NY: Columbia University Press.

Cahill, S. (2010). Black and Latino same-sex couple households and the racial dynamics of antigay activism. In J. Battle \& S. Barnes (Eds.), Black sexualities: Probing powers, passions, practices and policies (pp. 243-268). New Brunswick, NJ: Rutgers University Press.

Cahill, S., \& Jones, K. (2001). Leaving our children behind: Welfare reform and the gay, lesbian, bisexual and transgender community. New York, NY: Policy Institute of the National Gay and Lesbian Task Force.

Cahill, S., Battle, J., \& Meyer, D. (2003). Partnering, parenting, and policy: Family issues affecting Black lesbian, gay, bisexual, and transgender (LGBT) people. Race and Society, 6, 85-98. https://doi.org/10.1016/j. racsoc.2004.11.002
Carrillo, H. (2018). Pathways of desire: The sexual migration of Mexican gay men. Chicago, IL: University of Chicago Press.

Carroll, M. (2018a). Gay fathers on the margins: Race, class, marital status, and pathways to parenthood. Family Relations, 67, 104-117. https://doi. org/10.1111/fare. 12300

Carroll, M. (2018b). Managing without moms: Gay fathers, incidental activism, and the politics of parental gender. Journal of Family Issues, 39, 3410-3435. https://doi.org/10.1177/0192513X18783229

Cavalcante, A. (2015). Anxious displacements: The representation of gay parenting on Modern Family and The New Normal. Television \& New Media, 16, 454-471. https://doi.org/10.1177/1527476414538525

Chambers-Letson, J. (2018). After the party: A manifesto for queer of color life. New York, NY: NYU Press.

Chávez, K. (2013). Queer migration politics: Activist rhetoric and coalitional possibilities. Urbana, IL: University of Illinois Press.

Cho, J. (2009). The wedding banquet revisited: "Contract marriages" between Korean gays and lesbians. Anthropological Quarterly, 82, 401-422. https://doi. org/10.1353/anq.0.0069

Cianciotto, J. (2005). Hispanic and Latino same-sex couple households in the United States: A report from the 2000 Census. New York, NY: The National Gay and Lesbian Task Force Policy Institute.

Collins, P. H. (2000). Black feminist thought: Knowledge, consciousness, and the politics of empowerment. New York, NY: Routledge.

Collins, P. H. (2004). Black sexual politics: African Americans, gender, and the new racism. New York, NY: Routledge.

Compton, D., \& Baumle, A. (2018). Demographics of gay and lesbian partnerships and families. In N. Riley \& J. Brunson (Eds.), International handbook on gender and demographic processes (pp. 267-285). New York, NY: Springer.

Connell, R. (2007). Southern theory: Social science and the global dynamics of knowledge in social science. Boston, MA: Polity.

Conran, K., \& Brown, T. (2017). LGBT DREAMers and Deferred Action for Childhood Arrivals (DACA). Los Angeles, CA: The Williams Institute, UCLA School of Law.

Cross, C. (2018). Extended family households among children in the United States: Differences by race/ethnicity and socioeconomic status. Population Studies, 72, 235-251. https://doi.org/10.1080/00324728.2018. 1468476

Dang, A., \& Frazer, S. (2004). Black same-sex households in the United States: A report from the 2000 census. New York, NY: Policy Institute of the National Gay and Lesbian Task Force and the National Black Justice Coalition.

Dang, A., \& Vianney, C. (2007). Living in the margins: A national survey of lesbian, gay, bisexual and transgender Asian and Pacific Islander Americans. New York, 
NY: The National Gay and Lesbian Task Force Policy Institute.

DasGupta, S., \& DasGupta, S. D. (2010). Motherhood jeopardized: Reproductive technologies in Indian communities. In W. Chavkin \& J.-M. Maher (Eds.), The globalization of motherhood: Deconstructions and reconstructions of biology and care (pp. 131153). New York, NY: Routledge.

DeFilippis, J. (2016). What about the rest of us? An overview of LGBT poverty issues and a call to action. Journal of Progressive Human Services, 27, 143-174. https://doi.org/10.1080/10428232.2016.1 198673

DeFilippis, J. (2018). A new queer liberation movement and its targets of influence, mobilization, and benefits. In J. DeFilippis, M. Yarbrough, \& A. Jones (Eds.), Queer activism after marriage equality (pp. 81-107). New York, NY: Routledge.

Dozier, R. (2015). The power of queer: How "guy moms" challenge heteronormative assumptions about mothering and family. In B. Risman \& V. Rutter (Eds.), Families as they really are (pp. 458-474). New York, NY: W. W. Norton.

Dreby, J. (2015). U.S. immigration policy and family separation: The consequences for children's well-being. Social Science \& Medicine, 132, 245-251. https://doi. org/10.1016/j.socscimed.2014.08.041

Dunne, G. A. (2000). Opting into motherhood: Lesbians blurring the boundaries and transforming the meaning of parenthood and kinship. Gender \& Society, 14, 11-35. https://doi. org/10.1177/089124300014001003

Engebretsen, E. L. (2009). Intimate practices, conjugal ideals: Affective ties and relationship strategies among lala (lesbian) women in contemporary Beijing. Sexuality Research \& Social Policy, 6, 3-14. https:// doi.org/10.1525/srsp.2009.6.3.3

Evans-Campbell, T., Fredriksen-Goldsen, K., Walters, K., \& Stately, A. (2007). Caregiving experiences among American Indian Two-Spirit men and women: Contemporary and historical roles. Journal of Lesbian and Gay Social Services, 18, 75-92. https://doi. org/10.1300/J041v18n03_05

Farr, R., \& Patterson, C. (2009). Transracial adoption by lesbian, gay, and heterosexual couples: Who completes transracial adoptions and with what results? Adoption Quarterly, 12, 187-204. https://doi. org/10.1080/10926750903313328

Few-Demo, A., Humble, Á., Curran, M., \& Lloyd, S. (2016). Queer theory, intersectionality, and LGBTparent families: Transformative critical pedagogy in family theory. Journal of Family Theory \& Review, 8, 74-94. https://doi.org/10.1111/jftr.12127

Fong, R., \& McRoy, R. (Eds.). (2016). Transracial and intercountry adoption: Cultural guidance for professionals. New York, NY: Columbia University Press.

Gates, G. (2013a). LGBT adult immigrants in the United States. Los Angeles, CA: The Williams Institute, UCLA School of Law.
Gates, G. (2013b). LGBT parenting in the United States. Los Angeles, CA: The Williams Institute, UCLA School of Law.

Gilley, B. J. (2006). Becoming Two-Spirit: Gay identity and social acceptance in Indian country. Lincoln, NE: University of Nebraska Press.

Glass, V. (2014). "We are with family": Black lesbian couples negotiate rituals with extended families. Journal of GLBT Family Studies, 10, 79-100. https://doi.org/1 0.1080/1550428X.2014.857242

Glover, M., McKree, A., \& Dyall, L. (2009). Assisted human reproduction: Issues for takatapui (New Zealand indigenous non-heterosexuals). Journal of GLBT Family Studies, 5, 295-311. https://doi. org/10.1080/15504280903263702

Goldberg, A. (2019). Open adoption and diverse families: Complex relationships in the digital age. Oxford, UK: Oxford University Press.

Goldberg, A., Sweeney, K., Black, K., \& Moyer, A. (2016). Lesbian, gay, and heterosexual adoptive parents' socialization approaches to children's minority statuses. The Counseling Psychologist, 44, 267-299. https://doi.org/10.1177/0011000015628055

Goldberg, A., \& Smith, J. (2016). Predictors of race, adoption, and sexual orientation related socialization of adoptive parents of young children. Journal of Family Psychology, 30, 397-408. https://doi.org/10.1037/ fam0000149

Goldberg, S., \& Conron, K. (2018). Adult LGBT American Indians and Alaskan Natives per region of the United States. Los Angeles, CA: The Williams Institute, UCLA School of Law.

Gondouin, J. (2012). Adoption, surrogacy, and Swedish exceptionalism. Critical Race and Whiteness Studies Journal, 8, 1-20.

Grant, J., Mottet, L., Tanis, J., Harrison, J., Herman, J., \& Keisling, M. (2011). Injustice at every turn: A report of the national transgender discrimination survey. Washington, DC: National Center for Transgender Equality and National Gay and Lesbian Task Force.

Hakim, N. H., Molina, L. E., \& Branscombe, N. R. (2017). How discrimination shapes social identification processes and wellbeing among Arab Americans. Social Psychological and Personality Science, 9, 328-337. https://doi.org/10.1177/1948550617742192

Hamdi, N., Lachheb, M., \& Anderson, E. (2018). Muslim gay men: Identity conflict and politics in a Muslim majority nation. The British Journal of Sociology, 69, 1293-1312. https://doi. org/10.1111/1468-4446.12334

Hammonds, E. M. (1997). Toward a genealogy of Black female sexuality: The problematic of silence. In M. J. Alexander \& C. T. Mohanty (Eds.), Feminist genealogies, colonial legacies, democratic futures (pp. 170182). New York, NY: Routledge.

Han, C. (2015). Geisha of a different kind: Race and sexuality in Gaysian America. New York, NY: New York University Press. 
Han, C. (2017). Examining identity development among gay men of color. Sociology Compass, 11, 1-12. https://doi.org/10.1111/soc4.12503

Herrera, F. (2009). Tradition and transgression: Lesbian motherhood in Chile. Sexuality Research \& Social Policy, 6, 35-51. https://doi.org/10.1525/ srsp.2009.6.2.35

Hicks, S. (2011). Lesbian, gay and queer parenting: Families, intimacies, genealogies. Basingstoke, UK: Palgrave Macmillan.

Huang, S., \& Brouwer, D. (2018). Negotiating performances of "real" marriage in Chinese queer xinghun. Women's Studies in Communication, 41, 140-158. https://doi.org/10.1080/07491409.2018.1463581

Huang, Y. P., Brewster, M., Moradi, B., Goodman, M., Wiseman, M., \& Martin, A. (2010). Content analysis of literature about LGB people of color: 1998-2007. The Counseling Psychologist, 38, 363-396. https:// doi.org/10.1177/0011000009335255

Jacobson, H. (2016). Labor of love: Gestational surrogacy and the work of making babies. New Brunswick, NJ: Rutgers University Press.

James, S. E., Brown, C., \& Wilson, I. (2017). 2015 U.S. transgender survey: Report on the experiences of Black respondents. Washington, DC and Dallas, TX: National Center for Transgender Equality, Black Trans Advocacy, \& National Black Justice Coalition.

James, S. E., Jackson, T., \& Jim, M. (2017). 2015 U.S. transgender survey: Report on the experiences of American Indian and Alaska Native respondents. Washington, DC: National Center for Transgender Equality.

James, S. E., \& Magpantay, G. (2017). 2015 U.S. transgender survey: Report on the experiences of Asian, Native Hawaiian, and Pacific Islander respondents. Washington, DC and New York, NY: National Center for Transgender Equality \& National Queer Asian Pacific Islander Alliance.

James, S. E., \& Salcedo, B. (2017). 2015 U.S. transgender survey: Report on the experiences of Latino/a respondents. Washington, DC and Los Angeles, CA: National Center for Transgender Equality and TransLatin@ Coalition.

Johnson, E. P. (2018). Black. Queer. Southern. Women: An oral history. Chapel Hill, NC: The University of North Carolina Press.

Karpman, H., Ruppel, E., \& Torres, M. (2018). "It wasn't feasible for us": Queer women of color navigating family formation. Family Relations, 67, 118-131. https://doi.org/10.1111/fare.12303

Kastanis, A., \& Gates, G. (2013a). LGBT African Americans and African-American same-sex couples. Los Angeles, CA: The Williams Institute, UCLA School of Law.

Kastanis, A., \& Gates, G. (2013b). LGBT Asian and Pacific Islander individuals and same-sex couples. Los Angeles, CA: The Williams Institute, UCLA School of Law.
Kastanis, A., \& Gates, G. (2013c). LGBT Latino/a individuals and Latino/a same-sex couples. Los Angeles, CA: The Williams Institute, UCLA School of Law.

Kastanis, A., \& Wilson, B. (2014). Racelethnicity, gender, and socioeconomic wellbeing of individuals in samesex couples. Los Angeles, CA: The Williams Institute, UCLA School of Law.

Leibetseder, D. (2018). Queer reproduction revisited and why race, class, and citizenship still matter. Bioethics, 32, 138-144. https://doi.org/10.1111/bioe.12416

Lens, V. (2019). Judging the other: The intersection of race, gender, and class in family court. Family Court Review, 57, 72-87. https://doi.org/10.1111/ fcre. 12397

Lewin, E. (2009). Gay fatherhood: Narratives of family and citizenship in America. Chicago, IL: The University of Chicago Press.

Lynch, I., \& Morison, T. (2016). Gay men as parents: Analysing resistant talk in South African mainstream media accounts of queer families. Feminism \& Psychology, 26, 188-206. https://doi. org/10.1177/0959353516638862

Mays, V., Chatters, L., Cochran, S., \& Mackness, J. (1998). African American families in diversity: Gay men and lesbians as participants in family networks. Journal of Comparative Family Studies, 29, 73-87. https://doi.org/10.3138/jcfs.29.1.73

Menjívar, C., Abrego, L., \& Schmalzbauer, L. (2016). Immigrant families. Malden, MA: Policy Press.

Mohanty, C. (1984). Under Western eyes: Feminist scholarship and colonial discourses. boundary 2, 12/13, 333-358. https://doi.org/10.1057/fr.1988.42

Mohummadally, A. (2012). Pride and prejudice. Daily Life. Retrieved from http://www.dailylife.com. au/life-and-love/real-life/pride-and-prejudice20120228-1u0ki.html

Moore, M. R. (2011a). Invisible families: Gay identities, relationships, and motherhood among Black women. Berkeley, CA: University of California Press.

Moore, M. R. (2011b). Two sides of the same coin: Revising analyses of lesbian sexuality and family formation through the study of Black women. Journal of Lesbian Studies, 15, 58-68. https://doi.org/10.1080/10 894160.2010.508412

Moore, M., \& Stambolis-Ruhstorfer, M. (2013). LGBT sexuality and families at the start of the twenty-first century. Annual Review of Sociology, 39, 491-507. https://doi.org/10.1146/ annurev-soc-071312-145643

Moras, A., Shehan, C., \& Berardo, F. (2007). African American families: Historical and contemporary forces shaping family life and studies. In H. Vera \& J. Feagin (Eds.), Handbook of the sociology of racial and ethnic relations (pp. 145-160). New York, NY: Springer.

National Black Justice Coalition. (2012). LGBT families of color: Facts at a glance. Retrieved from http:// 
www.nbjc.org/sites/default/files/lgbt-families-ofcolor-facts-at-a-glance.pdf

Nebeling Petersen, M. (2018). Becoming gay fathers through transnational commercial surrogacy. Journal of Family Issues, 39, 693-719. https://doi.org/10.1177 /0192513X16676859

Nixon, L. (2013). The right to (trans) parent: A reproductive justice approach to reproductive rights, fertility, and family-building issues facing transgender people. William \& Mary Journal of Women and the Law, 20, 73-103.

Pande, A. (2015). Blood, sweat, and dummy tummies: Kin labour and transnational surrogacy in India. Anthropologica, 57, 53-62.

Pastrana, A., Battle, J., \& Harris, A. (2017). An examination of Latinx LGBT populations across the United States: Intersections of race and sexuality. New York, NY: Palgrave Macmillan.

Patterson, C., \& Tornello, S. (2010). Gay fathers' pathways to parenthood: International perspectives. Journal of Family Research, 22, 103-116. https://doi. org/10.2307/j.ctvdf0csb.11

Potgieter, C. (2003). Black South African lesbians: Discourses on motherhood and women's roles. Journal of Lesbian Studies, 7, 135-151. https://doi. org/10.1300/J155v07n03_10

Prendergast, S., \& MacPhee, D. (2018). Family resilience amid stigma and discrimination: A conceptual model for families headed by same-sex parents. Family Relations, 67, 26-40. https://doi.org/10.1111/ fare. 12296

Purkayastha, B. (2012). Intersectionality in a transnational world. Gender \& Society, 26, 55-66. https://doi. org/10.1177/0891243211426725

Pyke, K. (2000). "The normal American family" as an interpretive structure of family life among grown children of Korean and Vietnamese immigrants. Journal of Marriage and Family, 62, 240-255. https://doi. org/10.1111/j.1741-3737.2000.00240.x

Quiroz, P. (2007). Adoption in a color-blind society. Lanham, MD: Rowman \& Littlefield.

Roberts, D. (2009). Shattered bonds: The color of child welfare. New York, NY: Basic Books.

Rodriguez, J. (2014). Sexual futures, queer gestures, and other Latina longings. New York, NY: NYU Press.

Romero, V. (2005). Asians, gay marriage, and immigration: Family unification at a crossroads. Indiana International \& Comparative Law Review, 15, 337-347.

Ross, L., Epstein, R., Goldfinger, C., Steele, L., Anderson, S., \& Strike, C. (2014). Lesbian and queer mothers navigating the adoption system: The impacts on mental health. Health Sociology Review, 17, 254-266. https://doi.org/10.5172/hesr.451.17.3.254

Rudrappa, S., \& Collins, C. (2015). Altruistic agencies and compassionate consumers: Moral framing of transnational surrogacy. Gender \& Society, 29, 937959. https://doi.org/10.1177/0891243215602922

Ryan, M., \& Berkowitz, D. (2009). Constructing gay and lesbian parent families beyond the closet. Qualitative
Sociology, 32, 153-172. https://doi.org/10.1007/ s11133-009-9124-6

Ryan, M., \& Moras, A. (2017). Race matters in lesbian donor insemination: Whiteness and heteronormativity in co-constituted narratives. Ethnic and Racial Studies, 40, 579-596. https://doi.org/10.1080/014198 70.2016.1201581

Schneebaum, A., \& Badgett, M. V. L. (2018). Poverty in US lesbian and gay couple households. Feminist Economics. https://doi.org/10.1080/13545701.2018.1 441533

Singh, A., \& Shelton, K. (2011). A content analysis of LGBT qualitative research in counseling: A ten-year review. Journal of Counseling and Development, 89, 217-226. https://doi.org/10.1002/j.1556-6678.2011. tb00080.x

Smith, D. (1993). The standard North American family: SNAF as an ideological code. Journal of Family Issues, 14, 50-65. https://doi.org/10.1177/01925 13X93014001005

Spade, D., \& Rohlfs, R. (2016). Legal equality, gay numbers and the (after?)math of eugenics. The Scholar and Feminist Online, 13, 1-25.

Stormh $ø$, C. (2018). Still much to be achieved: Intersecting regimes of oppression, social critique, and 'thick' justice for lesbian and gay people. Sexualities. Advance online publication. https://doi. org/10.1177/1363460718790873

Stotzer, R. (2013). LGBTQI Hawai' $i$ : A needs assessment of the lesbian, gay, bisexual, transgender, queer, and intersex communities in the state of Hawai 'i. Supplement 2, findings by gender. Honolulu, HI: Myron B. Thompson School of Social Work, University of Hawai' $i$ at Mānoa.

Stotzer, R., Herman, J., \& Hasenbush, A. (2014). Transgender parenting: A review of existing research. Los Angeles, CA: The Williams Institute, UCLA School of Law.

Strmic-Pawl, H., Jackson, B., \& Garner, S. (2018). Race counts: Racial and ethnic data on the U.S. Census and the implications for tracking inequality. Sociology of Race and Ethnicity, 4, 1-13. https://doi. org/10.1177/2332649217742869

Sullivan, M. (2004). The family of woman: Lesbian mothers, their children, and the undoing of gender. Berkeley, CA: University of California Press.

Swarr, A., \& Nagar, R. (2003). Dismantling assumptions: Interrogating 'lesbian' struggles for identity and survival in India and South Africa. Signs: Journal of Women in Culture and Society, 29, 491-516. https:// doi.org/10.1086/378573

Tasker, F., \& Rensten, K. (2019). Social science research on heterosexual relationship dissolution and divorce where one parent comes out as LGB. In A. Goldberg \& A. Romero (Eds.), LGBTQ divorce and relationship dissolution: Psychological and legal perspectives and implications for practice (pp. 173-194). New York, NY: Oxford University Press. 
Taylor, R., Forsythe-Brown, I., Lincoln, K., \& Chatters, L. (2015). Extended family support networks of Caribbean Black adults in the United States. Journal of Family Issues, 38, 522-546. https://doi.org/10.1177 /0192513X15573868

van Eeden-Moorefield, B., Few-Demo, A., Benson, K., Bible, J., \& Lummer, S. (2018). A content analysis of LGBT research in top family journals 2000-2015. Journal of Family Issues, 39, 1374-1395. https://doi. org/10.1177/0192513X17710284

Ventura, R., Rodríguez-Polo, X., \& Roca-Cuberes, C. (2019). "Wealthy gay couples buying babies produced in India by poor womb-women": Audience interpretations of transnational surrogacy in TV news. Journal of Homosexuality, 66, 609-634. https://doi.org/10.108 0/00918369.2017.1422947
Vidal Ortiz, S., \& Martínez, J. (2018). Latinx thoughts: Latinidad with an X. Latino Studies, 16, 384-395. https://doi.org/10.1057/s41276-018-0137-8

Vora, K. (2012). Limits of "labor": Accounting for affect and the biological in transnational surrogacy and service work. South Atlantic Quarterly, 111, 681-700. https://doi. org/10.1215/00382876-1724138

Wekker, G. (2006). The politics of passion: Women's sexual culture in the Afro-Surinamese diaspora. New York, NY: Columbia University Press.

Wyman-Battalen, A., Dow-Fleisner, S., Brodzinsky, D., \& McRoy, R. (2019). Lesbian, gay, and heterosexual adoptive parents' attitudes towards racial socialization practices. Journal of Evidence-Informed Social Work. Advance online publication. https://doi.org/10.1080/2 3761407.2019.1576565 